\title{
Resilience of Young Women as Human Trafficking Victims
}

\author{
Yunita Sari and Khairunnisa
}

\begin{abstract}
This study aims to describe resilience of young women who were human trafficking victims. The used method is descriptive analysis. This study employs three adolescents, who were human trafficking victims, as the subjects of this study, who used to work as prostitutes in Garut, West Java, Indonesia. The data were collected through resilience questionnaires and semi-structured interviews composed by the researcher based on Grothberg's theory (1999). The result shows that one victim has high resilience while the two others tend to have low resilience. Parenting, support from significant persons, and social competences are the ultimate factors for the victim to have high inference.
\end{abstract}

Index Terms-Resilience, human trafficking, young women.

\section{INTRODUCTION}

Until today, Indonesia has been having ten unsolved problems, some of which include violence and neglect of vulnerable people, especially children, women, and poor people [1]. They get more attention since the number of violence and human trafficking of women are increasing. The woman trafficking becomes a complex matter due to their weak position and poverty factor, causing they are easily sold by traffickers. It is estimated that the victims of trafficking have reached over 40,000 people, and most of them are women and children [2]. UN (United Nations) defines trafficking in persons as the recruitment, transportation, transfer, harboring of receipt of persons, by means of the threat or use of force or other forms of coercion, of abduction, of fraud, of deception, of the abuse of power or of a position of vulnerability or of the giving or receiving of payments or benefits to achieve the consent of a person having control over another person for the purpose of exploitation [3].

The rampant cases of human trafficking in Garut, West Java, Indonesia are very alarming. Garut is the region with the highest number of trafficking compared to other regions in West Java. The high poverty level in Garut touching 85.5 percents is directly in line with the rampant human trafficking in Garut [4]. The cases of human trafficking in Garut also occur in adolescents who are experiencing changes in interest and appearance due to influences from peers. It, consequently, is very easy for traffickers to recruit them into the world of trafficking. They willingly comply with traffickers in the hope that they can change their economic status and help their parents.

Adolescents who have been victims of sexual exploitation will find it difficult to get out of the condition. The

Manuscript received July 10, 2013; revised September 16, 2013.

Yunita Sari and Khairunnisa are with the Bandung Islamic University, Indonesia (e-mail: yunitasari.psy@ gmail.com). increasing tension of emotion in adolescents due to social pressure creates instability when experiencing traumatic events. Adolescents who drop out of their schools face bad treatments from their social environments which give them pressure. The adolescents find themselves soiled, mostly of the time causing them unconfident, easily offended when greeted by others, and easily anxious when meeting strangers. They are embarrassed to leave their homes for months, prefer being alone, withdrawn from their environments, and think that other people will not like them anymore.

Based on the result of the interview, it shows that there are adolescents who are victims of trafficking are able to continue their life. They can continue their studies well, be active in their environments, and consider the traumatic experiences as life lessons. Supports from family and friends are very helpful for their life development. They get confident to solve their problems. They do not feel shunned by their friends and as usual keep get along with. They can plan their future and become optimistic about their better future.

Reference [5] says the human capacity to face, overcome, and change the painful experience is called resilience.

This study aims to obtain empirical data about the description of resilience of human trafficking victims in an institution of women empowerment in Garut. The result of this study is expected to give benefits for both the institution of women empowerments and the victims in order to develop their potency, to prevent stigma of human trafficking as a barrier to actualize their potency, and to open people's mind to give opportunities for them to develop their potency.

\section{METHOD}

The method used in this study was descriptive one. This study was conducted on young women who were victims of human trafficking in an institution of women empowerment in Garut, West Java, Indonesia. This study applied a population with the following criteria:

- were victims of human trafficking for the purpose of commercial sex workers

- have been already in their family environment and are willing to be the subject of this study

- no more experience traumatic events, so are able to respond normally

Accordingly, the subjects who participated in this study were three victims of human trafficking in an institution of women empowerment in Garut.

The instruments used by the researcher were resilience questionnaire and semi-structure interview composed based 
on Grothberg's theory [5]. The list of questions asked to the respondents was based on self-reports consisting of personal experiences, personal beliefs, or personal knowledge.

The technique of analyzing data used in this study applied descriptive statistics. The technique of analyzing frequency of the respondents' resilience applied percentage statistic method (\%). It allowed to find out how high frequency of the victims' resilience as well as sources of high and low resilience.

\section{RESULT AND DISCUSSION}

This study involved 15-18 years-old teenagers of human trafficking victims as subjects in Garut. The subjects were trafficked for the purpose of commercial sex and sexual exploitation. Commercial sexual exploitation is a form of human trafficking requiring special attention because the victims encounter physical, sexual, and psychological abuse. The following (See Table I) of the subjects.

TABLE I: DEMOGRAPHY OF THE SUBJECT

\begin{tabular}{|c|c|c|c|c|c|}
\hline Subjects & $\begin{array}{c}\text { Current age } \\
\mathbf{( 2 0 1 3 )}\end{array}$ & $\begin{array}{c}\text { Age as a } \\
\text { victim }\end{array}$ & Last education & Marital Status & $\begin{array}{c}\text { Socioeconomic } \\
\text { status (SES) }\end{array}$ \\
\hline $\mathrm{A}$ & 17 & 16 & $\begin{array}{c}\text { Secondary school } \\
\text { (not graduate) }\end{array}$ & Single & Low SES \\
\hline $\mathrm{B}$ & 17 & 16 & $\begin{array}{c}\text { Secondary school } \\
\text { (graduate) }\end{array}$ & $\begin{array}{c}\text { Married (4 month } \\
\text { after the tragedy) }\end{array}$ & Low SES \\
\hline $\mathrm{C}$ & 18 & 17 & $\begin{array}{c}\text { Secondary school } \\
\text { (graduate) }\end{array}$ & Single & Low SES \\
\hline
\end{tabular}

Teenager is a transitional period experienced by individuals. During this period, teenagers show instability in attitude, appearance, interest, and emotion. In addition, teenagers are still in a phase in which most of them cannot make important decisions maturely. Their low socioeconomic background and poor understanding about life in big cities and trafficking make traffickers easier to recruit them into the trafficking world. They are forced to have sex to satisfy sexual need of men that they never want. As a lure to recruit teenagers, they are promised to get a job as waiters in a restaurant with a big salary outside the town they live in.

Human trafficking in teenagers for the purpose of commercial sexual exploitation influences not only on their physical development but also on their psychological one continuously. This is because their development of emotion is still unstable and also the value of virginity in Indonesian culture is highly honored. Lack acceptance by society to the victims who have returned to their hometown causes particular pressure. They get embarrassed to leave home, withdraw themselves from society, feel hard to put trust in someone new, do not want to continue their study because they are afraid of getting a ribbing from their friends, get angry at traffickers, lose orientation, feel that other people do not like them, and feel inferior to their friends.

Teenagers have strong desire to be appreciated and accepted by their peers and groups. They will be happy if they are accepted by their groups. They, in contrast, will be very depressed and anxious when expelled and belittled by their groups [6]. In this period, they tend to spend more time outdoors and are more dependent on their friends. Instead of their family, their peers have more significant influence on their attitudes, interests, appearance and behavior [7]. Reference [7] describes the influence of peers for teenagers as a place where they can test themselves and others. In the group, they form and improve their concept of self. The group can provide a world where they can socialize. The existing values are not the ones set by adults, but by their peers.

With the condition they have experienced, the victims of human trafficking will make efforts to adjust and live on.
They are hoped to learn the patterns of behavior, values, and characteristics that they should have in order to avoid such traumatic conditions. Some of them survive successfully, but some do not. According to the concept of psychology, this is called resilience. Reference [8] says that resilience is the universal capacity by which individual, group or community can prevent, minimize, and strive against destructive impacts when they undergo a disaster.

Reference [5] also explains that each individual has a variety of sources to be resilient. The first source derives from external supports, assistance, and resources to improve flexibility (I Have). Teenagers, the victims of human trafficking, have a family who are still willing to accept them, to provide supports, and to become role models. The second source is the one coming from self ( $\mathrm{IAm}$ ). Teenagers feel that there are always people who love them, believe themselves to have better life by learning from their experiences, and are also confident with their competence to be independent. Finally, the third source derives from interpersonal and problem solving skills (I Can). Teenagers are able to communicate their needs to others, are able to get help they need, and are able to cope with problems they encounter. With those sources, teenagers are able to prevent, minimize, and strive against destructive impacts after experiencing the disaster as the victims of human trafficking.

The victims of human trafficking are potential to be resilient; however, what makes them different is that each individual has different comprehension on the three sources they have. The comprehension can be seen by comparing each of the sources. The comparison among the sources can be reinforced with the fulfillment of stages of establishment of resilience (building blocks) in an individual by the environment, especially family, occurring in every developmental stage. Reference [5] suggests five building blocks as the basis of reinforcing the sources of resilience, consisting of trust, autonomy, initiative, industry, and identity. This formation begins at the stage of trust, which mostly forms the aspect I Have. Each individual has someone who can be trusted allowing them to feel safe, pleasant, and prosperous. Then, in the stage of autonomy and identity, mostly forming the aspect I Am, individuals 
can be independent and confident, forming who they will be. In the stage of initiative and industry forming the aspect $I$ Can, individuals are potential to develop in their social life by actively participating in their environment. These stages of establishment (building blocks) determine whether an individual has high resilience or not (see Table II).

\begin{tabular}{ccc}
\multicolumn{2}{c}{ TABLE II: RESILIENCE PARADIGM } \\
\hline Component & Definition & $\begin{array}{c}\text { Building } \\
\text { Blocks }\end{array}$ \\
\hline I Have & Support from & Trust \\
& environment to & \\
& improve resilience & \\
I Am & Internal motivation, & Autonomy \\
& such as confidence, & Identity \\
& self-esteem, and & \\
& reponsibility & \\
I Can & Interpersonal and & Initiative \\
& prolem solving skills & Industry \\
\hline
\end{tabular}

The following is the result of this study:

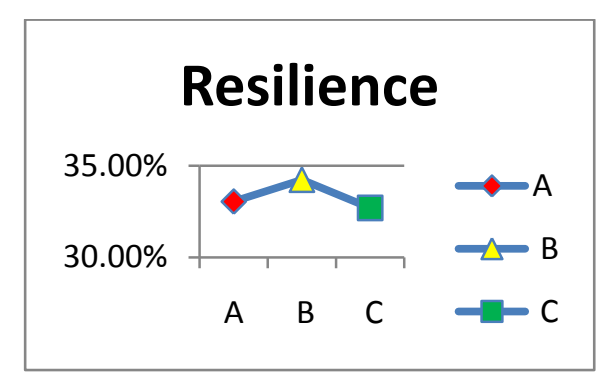

Fig. 1. The results of overall resilience measurement.

Based on the Fig. 1, among the three subjects, subject B has the highest resilience competence, while subject $\mathrm{A}$ and subject $\mathrm{C}$ have low resilience competence. The resilience competence of each subject is highly influenced by the sources I Have, I Am, and I Can which reinforce the subjects ability in preventing, minimizing, and striving against negative impacts caused by the trafficking. The individuals are considered to have high resilience if the three sources are in high categories. In subject B, the three sources are in a high category, while in subject $\mathrm{A}$ and subject $\mathrm{C}$, the sources are not.

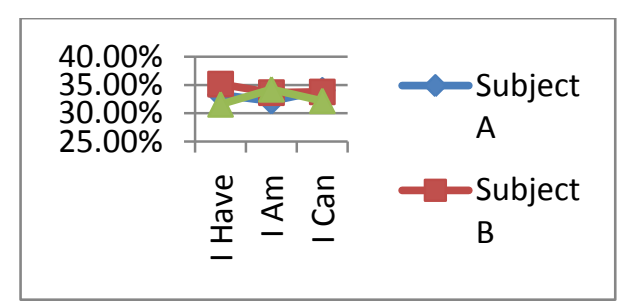

Fig. 2. Resilience form three sources.

Based on the Fig. 2, the resilience competence of subject B derives from I Have, I Am, and I Can. The most significant source in subject B is I Have. It means that subject B can come up from the difficult situation as a result of the trafficking. She uses help and power coming from outside more frequently. The subject has a mother and a husband who always support, guide, and encourage her to share every problems. Subject B also has the sources I Am and I Can although they are not as high as the source I Have.
The subject can find out her power. She is able to be independent and find out her strengths and weaknesses ( $I$ $A m)$. She has a mother who always asks her to discuss and appreciate her actions. This makes the subject confident to have a better life although she was a victim of trafficking ( $I$ $A m)$. Furthermore, subject B has the ability to resolve both personal and interpersonal problems. Subject B is a friendly, sociable, and adaptable person. She has a lot of friends and often helps them who have problems. Many of her friends help and support her so that she is able to overcome the trauma she feels after being the victim of trafficking. Reference [9] says that there are functions of friendship, they are companionship, stimulation, ego support, social comparison and affection and intimacy. Friendship provides a warm, close, trusting relationship with another individual. Intimacy in friendship is characterized by self-disclosure and the sharing of private thoughts.

Subject $\mathrm{A}$ and subject $\mathrm{C}$ have low resilience competence. This is because not all of the sources are in high categories. However, subject A has dominant sources of resilience on $I$ Have and I Can, while subject $\mathrm{C}$ has a dominant source of resilience on $I \mathrm{Am}$.

Subject A has the high source on I Have. It means that the subject has the external sources of strength by which can be used to cope with encountered difficulties. The subject also is able to resolve every matter, and has the ability in social and interpersonal relationships. On the source of I Have, the subject has a loving and caring family. Her mother has a central role in giving affection and giving rules to the children. In addition, the subject has a boyfriend who is always with her. Her mother always helps her without being asked, but she frequently complains to the subject when the subject cannot do in accordance to what her mother wishes so that the subject cannot act what she wants. Her mother always asks the subject to do things according to the rules and decisions that her mother has made. Subject A always asks for advice to take decision from her mother because she is afraid what she is doing is wrong. As a result, she is getting dependent in solving problems and is not confident with her abilities. This makes the source $I A m$ in a low category. A lack of independent on the subject in solving problems makes her dependent on other people. She feels that she cannot find a solution of the problems. As a result, she always needs other people to communicate what she feels. It, therefore, is easy for her to share and communicate with other to get a solution. This makes the source I Can have a high category.

A recent study of third-through ninth- graders, though, revealed that one aspect of girls' social support in friendship may have costs as well as benefits [10]. In the study, girls' co rumination (as reflected in excessively discussing problems) predicted not only an increase in positive friendship quality but also an increase rumination as well as an increase in depressive and anxiety symptoms. One implication of the research is that some girls who are vulnerable to developing internalized problems may go undetected because they have supportive friendship. This also occurs on subject $\mathrm{A}$ and subject $\mathrm{B}$ showing a high source I Can (see Fig. 2).

Subject $\mathrm{C}$ has the dominant source forming resilience on $I$ $A m$. It means that she has internal power including self- 
confidence, self-esteem, and responsibility. This power can be used to cope with difficult situations the subject experiences either as the victim of human trafficking or after being in her family environment. She has divorced parents. She is the second of the three children. Her parents divorced when she was 12 years old. Then, when she was 14 years old, her mother remarried a widower with three children. Since the second marriage of her mother, she feels that her mother takes care more of her half-sisters. When she shares her problems with her mother, she only listens to her without giving a solution. This forces the subject to resolve every problem by herself. She feels that her family does not care about her. With such a family background, the subject does not get sufficient support from others so that she has a low category on I Have. However, she has a high category on I Am. This is due to the lack of family support. She feels that she does not need anyone else since she is confident in her ability and thinks she is able to solve every problem ( $I$ $A m)$. Consequently, the subject is less able to establish social relations flexibly, cannot easily put her trust, cannot communicate her needs, and does not care about other people. She, as a result, has a low category on I Can. The subject assumes that other people cannot help with her life problems. She has to struggle for survival by herself.

Reference [11] says that remarried families are more likely to be unstable than first marriage, with divorce more likely to occur, especially in the first several years of the remarried family, than in the first marriages. Second marriages have higher levels of conflict, more complications, and higher rates of dissolution than first marriages. Stepmothers often feel overwhelmed by instant childrearing and housekeeping responsibilities as they marry men with children [12]. Adults who get remarried have a lower level of mental health (higher rates of depression, for example) than adults in first marriages, but remarriage often improves the financial status of remarried adults, especially women. The complex histories and multiple relationships make adjustment difficult in a stepfamily [13]-[14]. This is in line with what subject $\mathrm{C}$ has experienced. Her mother who has burden from her second marriage does not show her care on subject $\mathrm{C}$. The remarriage makes relationship between the mother and her daughter from the first marriage unharmonious. Consequently, subject $\mathrm{C}$ tends to have a low source I Have and a high source I Am (See Fig. 2).

References [15]-[18] say that parents play very important roles in adolescent development. Although adolescent are moving forward independence, they still need to stay connected with families. Competent adolescent development is most likely when adolescents have parents who show them warmth and mutual respect, demonstrate sustained interest in their lives, recognize and adapt to their cognitive and socio-emotional development, communicate expectations for high standards of conduct and achievement, and display constructive ways of dealing with problems and conflict [13]-[19]. These ideas coincide with reference [20][21], dealing with authoritative parenting style.

Overall, based on the all subjects, mothers, apprantely, are an essential Fig. in establishing resiliance on victims of human trafficking, especially commercial sex ones. This is because resiliance is shaped by the building block occuring in mother's treatment to their children. Reference [12] says from infancy through adolescence, mother are more likely than fathers to have a managerial role in parenting.

\section{CONCLUSION}

Based on the result of analysis, there is only one subject of the three subjects who has high resilience competence. The subject with high resilience has sources of external power, internal power, and high interpersonal and social ability to help improve her resilience. The subjects with low resilience competence also have all aspects of I Have, I Am, and I Can or have two high aspects, but the other is low.

To sum up, the most important factor to improve resilience of the subjects is parenting instilled in the family. It is external force coming from significant persons, who are helpful in improving their resilience, like mothers. In addition, the ability of establishing relationship with other people is also helpful in improving their resilience.

There are some suggestions in this study. They are:

1) For institutions of woman empowerments in Garut, the result of this study can be a reference to hold counseling for victims of human trafficking, their families, and also for all teenagers who are not the victims. For the victims, they had better to get trainings and counseling to overcome the trauma. For the victims' families, they had better to get trainings how to handle and support the victims. For teenagers who are not the victims, they had better to have knowledge and information how to recognize and keep away from the traffickers.

2) For those who are interested in this issue, they are expected to investigate further about the types of care families can take to help the victims of human trafficking. They, hopefully, are able to become resilient.

\section{REFERENCES}

[1] Koran Demokrasi Indonesia. (July 20, 2012). 10 Permasalahan Utama Bangsa Indonesia di Tahun 2012. [Online]. Available: http://demokrasiindonesia.wordpress.com/2012/07/20/10 permasalahan-utama-bangsa-indonesia-tahun-2012/

[2] Jurnal Perempuan Untuk Pencerahan Dan Kesetaraan, Pendampingan Korban Trafiking, Jakarta: Yayasan Jurnal Perempuan, no. 36, pp. 1, July 2004.

[3] IDLO Rubric. (26 January 2008). Human Trafficking. Aceh: IDLO and Harian Serambi Indonesia. [Online]. Available: http://www.idlo.int/DOCNews/Human_trafficking_ind.pdf

[4] Pikiran Rakyat. (April 20, 2012). Garut Memiliki Presentase Terbesar untuk Tingkat Kemiskinan Anak. [Online]. Available: http://m.pikiran-rakyat.com/node/185339

[5] E. H. Grothberg, Tapping Your Inner Strength How to Find the Resilience to Deal with Anything, Oakland: New Harbinger Publications, 1999, pp. 5-85.

[6] J. W. Santrock, Adolescence Developmental, Jakarta: Erlangga, 2003, pp. $219-224$

[7] E. B. Hurlock, Psikologi Perkembangan, Jakarta: Erlangga, 1980, pp. 213-214.

[8] E. H. Grothberg, "Guide to promoting resilience in children strengthening the human spirit," The Series Early Childhood Development: Practice and Reflections, The Hague: Bernard van Leer Foundation, no. 8, 1995.

[9] J. M. Gottman and Parker, Conversation of Friends, New York: Cambridge University Press, 1987.

[10] A. J. Rose, W. Carlson, and E. M. Waller, "Prospective association of co rumination with firendship and emotional adjustment: considering the socioemotional trade-offs of co-rumination," Developmental Psychology, 2007, vol. 43, pp. 1019-1031.

[11] L. J. Waite, "Marriage," in D. Carr (ed.), Encyclopedia of the Life Course and Human Development, Boston: Gale Cengage, 2009. 
[12] T. R. Howe, Marriages and Families in the 21st Century, U.K: Wiley-Blackwell, 2012, ch. 12, pp. 435.

[13] J. W. Santrock, A Topical Approach to Life Span Development, 6th edition, New York: McGraw-Hill Companies, 2012, ch. 14.

[14] K. M. Pann and M. C. Burnett, "Remarriage and re-coupling: A stress perspective," in P. C. Mckenry and S. J Price (Eds.), Families and Change, 3rd ed., Thousand Oaks, CA: Sage, 2005, pp. 456.

[15] B. Laursen and W. A. Collins, "Parent-child relationships during adolescence," in R. M. Lerner and L. Steinberg (Eds), Handbook of Adolescent Psychology, 3rd ed., New York: Wiley, 2009.

[16] J. G. Smetana, "The role of trust in adolescent-parent relationships: To trust you is to tell you," in K. Rotenberg (Ed.) Trust and Trustworthiness during Chiledhood and Adolescence, New York: Cambridge University Press, 2010, pp. 223-246.

[17] J. G. Smetana, Adolescents, Families, and Social Development, New York: Wiley-Blackwell, 2011.

[18] J. G. Smetana, "Adolescents' social reasoning and relationships with parents: Conflict and coordinations within and across domains," in E. Amsel and J. Smetana (Eds.), Adolescent Vulnerabilities and Opportunities: Constructivist and Developmental Perspectives, New York: Cambridge University Press, 2011.

[19] S. A. Small, Preventive Programs that Support Families with Adolescents, Washington D.C: Carnegie Council on Adolescent Development, 1990.

[20] D. Baumrind, "Current pattern of parental authority," Developmental Psychology Monographs, vol. 4, 1971.
[21] D. Baumrind, "Effective parenting during the early adolescent transition," in P. A. Cowan and E. M. Hetherington (Eds), Advances in Family Research, Hillsdale, NJ: Erlbaum, vol. 2, 1991.

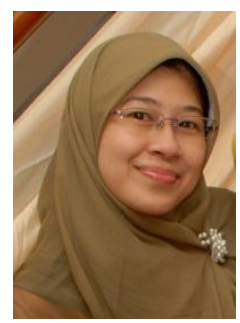

Yunita Sari is a psychologist, who was born in Palembang, June 24, 1981. She got her bachelor degree majoring psychology program in Bandung Islamic University, Bandung, Indonesia in 1999. In the same year, she continued her study to pursue Master degree majoring developmental psychology in Padjajaran University, Bandung, Indonesia. She, finally, got the degree in 2007.

Since 2002, she actively participated as a speaker, a moderator, and a trainer in many events and seminars related to her field. Currently, she works as a lecturer in Bandung Islamic University, Bandung. She is also active as a counselor in Al Irsyad Satya School, Bandung. There are some works she has written. One of them is Sayang Suka Gaya Apa?A Book of Communication for Couples (Jakarta, Indonesia: Cicero, 2010). Her research mainly focuses on family development, parenting, teenagers, and marital communication.

Mrs. Sari joins some institutions, including HIMPSI (Indonesia Association of Psychology), API (Association of Islamic Psychology), and IPPI (Indonesia Association of Developmental Psychology). 